\title{
Comparison of chili pepper breeding populations for agronomic traits and polygenic resistance to Phytophthora blight
}

\author{
Bekir Bülent Arpaci ${ }^{1} \mathbb{D}$; Kerim Karataş ${ }^{2} \mathbb{D}$ \\ ${ }^{1}$ Faculty of Agriculture, Kilis 7 Aralik University, Turkey; bbarpaci@kilis.edu.tr; ${ }^{2}$ East Mediterranean Transitional Zone Agricultural Research \\ Institute, Kahramanmaras, Turkey; kerim_krts@hotmail.com
}

\begin{abstract}
Belonging to the Oomycete class, Phytophthora capsici has wide range of host profile and is responsible for many devastating diseases in many countries. In addition to time consuming problem for transferring resistance to susceptible varieties, backcrossing method causes losing of genes providing resistance to susceptible varieties. In this study transferring $P$. capsici resistance genes to susceptible chili pepper lines was aimed during the extensive breeding period and resistant lines were confirmed by marker assistance. Two different breeding populations from CM334 and PM217 were compared by stem inoculation test to determine receptivity, inducibility, and stability resistance component. CM334 was found more effective for transferring all resistance components while PM217 was found suitable for keeping agronomic traits along with two important resistance component inducibility and stability. These two resistant components were found highly correlated to length of stem necrosis. C-29 and C-18 have been improved from CM334 as resistant as CM334; P-73 and P-77 have been improved satisfactorily resistant and yielded lines from PM217. Marker assisted selection proved that resistance of lines differentiated phenotypically despite the genotypes have the same genes.
\end{abstract}

Keywords: Capsicum annuum, Phytophthora capsici, resistance component, molecular markers, crop breeding.

\section{RESUMO}

Comparação de populações melhoradas de pimenta para características agronômicas e resistência poligênica à queima das folhas por Phytophthora

Pertencente à classe Oomycete, Phytophthora capsici possui amplo perfil de hospedeiros e é responsável por muitas doenças devastadoras em muitos países. Além da demora na transferência da resistência a variedades suscetíveis, o método de retrocruzamento causa perda de genes que fornecem resistência a variedades suscetíveis. Neste estudo, genes de resistência a $P$. capsici foram transferidos para linhagens de pimenta suscetíveis durante o período de melhoramento e as linhagens resistentes foram confirmadas pelos marcadores assistentes. Duas populações de melhoramento, CM334 e PM217, foram comparadas pelo teste de inoculação do caule para determinar o componente de resistência à receptividade, inducibilidade e estabilidade. O CM334 foi considerado mais eficaz para transferir todos os componentes de resistência, enquanto o PM217 foi considerado adequado por manter as características agronômicas, juntamente com dois componentes importantes de resistência, a inducibilidade e estabilidade. Esses dois componentes resistentes foram altamente correlacionados com o comprimento da necrose do caule. C-29 e C-18 foram aprimorados do CM334, sendo tão resistentes quanto o CM334; P-73 e P-77 foram aprimorados e considerados satisfatoriamente resistentes e produziram linhagens a partir de PM217. A seleção de marcadores assistentes provou que a resistência das linhagens se diferenciou fenotipicamente apesar dos genótipos possuírem os mesmos genes.

Palavras-chave: Capsicum annuum, Phytophthora capsici, componentes de resistência, marcadores moleculares, melhoramento.

\section{Received on December 27, 2018; accepted on September 18, 2019}

$\mathrm{D}$ ue to widespread cultivation of pepper in the world, harmful pests and diseases caused by fungi, viruses and bacteria on pepper have been prevalent. Belonging to the Oomycete, Phytophthora capsici is the most destructive disease of pepper in the world (Barchenger et al., 2018). Responsibility of many devastating diseases caused by $P$. capsici and wide range of host profile such as Solanaceous (pepper, tomato, eggplant) and Cucurbit (cucumber, melon, pumpkin) crops transforms it into the most destructive disease for many crops (Hausbeck \& Lamour, 2004). The pathogen causes root and fruit rot, stem and foliar blight on pepper plants (Iribarren et al., 2019). Root rot is the most observed symptom (Alcantara \& Bosland, 1993).

The most cost-effective method for preventing Phytophthora blight is to use resistant cultivars. Barksdale et al. (1984) explained P. capsici resistance with irregular dominance along with modifier genes affected by environmental conditions. Recent studies indicated that resistance to P. capsici is polygenic (Thabuis et al., 2003; Mallard et al., 2013). The polygenic resistance to $P$. capsici was examined in four resistance components: receptivity (REC), inducibility (IND), 
stability (STA) and root rot index (RRI). Receptivity is measured when the pathogen spreads in early infection process $3^{\text {rd }}$ day of post inoculation (DPI), of the plant. Inducibility means the deceleration of the necrosis length between the $3^{\text {rd }}$ and the $10^{\text {th }}$ DPI. Stability is the average speed of necrosis length between the $14^{\text {th }}$ and the $21^{\text {st }}$ DPI (Thabuis et al., 2004a) and the resistant genotypes stop the progressing of disease. Receptivity, inducibility and stability are quantitatively evaluated by the stem inoculation tests on both young and adult plants (Pochard \& Daubèze, 1980) while root rot index is a semi-quantitative criterion useful to determine the resistance of young plantlets (Thabuis et al., 2004a). Quantitative resistance is more durable than qualitative resistance (Pilet-Nayel et al., 2017).

In addition to time consuming problem for transferring resistance to susceptible varieties, backcrossing method causes loss of genes providing resistance to susceptible varieties (Palloix et al., 1990). Specific race host interaction has been referred by Sy et al. (2005) to manage Phytophthora resistance breeding program in consideration of gene to gene theory (Monroy-Barbosa \& Bosland, 2011).

Over the past years, many quantitative trait loci (QTL) have been detected and several molecular markers have been reported related to resistance to $P$. capsici in pepper (Thabuis et al., 2004a; Quirin et al., 2005; Mallard et al., 2013). Thabuis et al. (2004b) have determined the QTL (Phyto 6.1.) on $6^{\text {th }}$ chromosome in the populations improved by recurrent selection using the markers ASC 012 and ASC 014. Bonnet et al. (2007) have identified 8 QTL on $1^{\text {st }}, 4^{\text {th }}, 5^{\text {th }}, 6^{\text {th }}$, and $11^{\text {th }}$ chromosomes and observed that 4 chromosomes affect many of the resistance components.

ASC037 on P5 and ASC035p on P10 markers used in this study are significantly correlated to receptivity and stability components while ASC 031 has a weak correlation to root rot index and stability on P2. CAPS and SCAR markers developed by Thabuis et al. (2004a) were used in this study to confirm the resistance of improved chili pepper lines because of digenic interaction on both markers and association with root rot index resistance. Transferring P. capsici resistance to susceptible chili pepper lines was aimed during extensive breeding period. Forty-five improved lines were evaluated for their resistance to $P$. capsici and agronomical traits. During breeding program, three resistance genes could be transferred to Sena chili pepper cultivar widely grown for dried pepper production.

\section{MATERIAL AND METHODS}

\section{Isolation, production and conservation of $P$. capsici isolates}

Open field chili pepper cultivation areas were surveyed in Kahramanmaraş and pepper stem samples which had Phytophthora blight symptoms were collected. Eleven of the fifty-five fields infected by the pathogen widespread were surveyed. Five isolates were cultured and tested for aggressiveness on CM334 and Sena chili pepper variety which was commercial and susceptible to the pathogen (data not shown). One aggressive isolate from Doganlıkarahasan was used as inoculum.

\section{Stem inoculation tests}

The mycelium discs were placed on the cutting of the stem as described by Pochard \& Daubèze (1980). An aluminium sheet was wrapped on the top of the stem in which was plugged a mycelium disc to prevent drying of the inoculum. The progression of fungal necrosis from top of the stem to base was measured with digital caliper 3, 10, 14 and 21 days after stem inoculation. Receptivity was measured in early infection process $3^{\text {rd }}$ day post inoculation (DPI) inducibility was measured between $3^{\text {rd }}$ and the $10^{\text {th }}$ DPI and stability was the average speed of the stem necrosis measured as $\mathrm{mm}$ day $^{-1}$ between the $14^{\text {th }}$ and the $21^{\text {st }}$ DPI (Lefebvre \& Palloix, 1996).

\section{Breeding population}

The lines were improved from two breeding populations. One of the breeding populations was derived from crosses between the resistant donor Criollo de Morelos 334 (CM334) and KM211 which had been selected as resistant to P. capsici from Kahramanmaraş chili pepper population. The other breeding population was obtained by crossing PM217=PI201234 and KM211. PM217 (abbreviated as PM male) with KM211 (abbreviated as K female) and CM334 (abbreviated as CM male) with KM211 (female) were crossed independently and 106 individuals were self-pollinated for three times during three years. Two genotypes were selected from CMK and PMK populations. These two new resistant lines were independently crossed by Sena which was the susceptible chili pepper variety. Two independent $F_{1}$ progenies were not backcrossed to susceptible recipient but self-pollinated and submitted to screening tests. The most resistant individuals were backcrossed to susceptible recipient Sena variety and self-pollinated again. $\mathrm{CMKSeF}_{3}$ and $\mathrm{PMKSeF}_{3}$ populations were used as new resistant sources through 86 individuals according to stem inoculation test results. After two backcrossings to Sena and self-pollination alternately, 45 lines were selected and subjected to stem inoculation tests. Improved lines originated from PM217 were indicated with P letter and those of CM334 indicated with $\mathrm{C}$ letter at the beginning of the line numbers. (Figures 1,2).

\section{Marker-assisted selection of improved lines}

Total DNAs were purified from pieces of leaves $(0.1 \mathrm{~g})$ of improved 45 chili pepper lines backcrossed to Sena by both resistance sources originated from PM217 and CM334 with the TriReagent kit (Molecular Research Centre Inc.) described as protocols. CAPS markers (ASC037 and ASC031) and SCAR marker (ASC035p) were used to assign resistance to Phytophthora blight (Thabuis et al., 2004a; Lefebvre et al., 1995). EcoRI and HaeIII endonucleases were used to determine codominance for ASC037 and ASC031 respectively. PCR and digested products were analyzed by capillary electrophoresis. The base sizes were determined by using Qiaxcel Advanced System with AM320 method and DNA scanning cartridge 
at the electrophoretic analysis of PCR products.

\section{Evaluation of agronomic traits}

Forty-five $\mathrm{BC}_{2} \mathrm{~S}_{4}$ lines improved from both resistance sources were evaluated for yield and fruit characteristics in 2016 under field conditions from May to September in Kahramanmaraș placed South East Anatolian Region of Turkey. The field was drip irrigated and fertilized (160 $\mathrm{kg} \mathrm{ha}^{-1} \mathrm{~N}, 20 \mathrm{~kg} \mathrm{ha}^{-1} \mathrm{P}_{2} \mathrm{O}_{5}$ and 160 $\mathrm{kg} \mathrm{ha}^{-1} \mathrm{~K}_{2} \mathrm{O}$ ) during experiment. Lines were evaluated in augmented design of 3 blocks with 20 plants. Seven control varieties Sena, Maraş-1, S. Demre, Carliston, H46, BT 46 and PR 90 were repeated in each block to calculate variance. The average fruit weight $(\mathrm{g})$, fruit length $(\mathrm{mm})$, fruit width $(\mathrm{mm})$ and the fruit flesh thickness ( $\mathrm{mm}$ ) were measured. All plots were harvested two times when the fruits were matured, and yield values were transformed to yield per hectare.

\section{Statistical analysis}

Speed of stem necrosis and necrosis length of the $\mathrm{CMKSe} B \mathrm{C}_{2} \mathrm{~S}_{4}$ and $\mathrm{PMKSe} B \mathrm{C}_{2} \mathrm{~S}_{4}$ populations were performed by Analysis of Variance (ANOVA) after checking the variance homogeneity. Means were compared by LS Means Differences Tukey HSD multiple comparison tests. Data obtained from agronomic traits were also performed by ANOVA and means were compared by LS Means Differences Student's t test. Two breeding populations were compared by pairing means with t-test. JMP statistical software version 5.0.1 was used to calculate and compare means. Pepper lines were grouped by Principal Component Analysis related to speed of stem necrosis $\left[3^{\text {rd }}\right.$ day (REC) $10^{\text {th }}$ $14^{\text {th }}$ day (IND) $14^{\text {th }}-21^{\text {st }}$ day (STA) $]$ and length of stem necrosis values.

\section{RESULTS AND DISCUSSION}

\section{Resistance of the breeding populations}

Three resistance components differed by improved lines derived from different resistant sources CM334 and PM217. The means of $\mathrm{BC}_{2} \mathrm{~S}_{4}$ population improved from CM334 and PM217 were significantly dissimilar for receptivity, inducibility and stability and it was verified by t-test. CM334 was a more effective genotype to transfer all three components of $P$. capsici resistance to its generations. Population derived from CM334 especially resisted to the pathogen at the inducibility and stability stage (Table 1).

Plants were arranged in four phenotypic groups as high level resistant, resistant, moderately resistant and low level resistant according to their resistance component receptivity, inducibility, and stability. The first phenotypic group was classified as high level resistant including C-18, C-29 and CM334 which had low speed of stem necrosis related to three resistance components corresponding to receptivity, inducibility and stability stage (Figure 2). These three phenotypes which had the shortest length of stem necrosis after 21 days of inoculation and lines were separated from other phenotypes according to principal component analysis. Transferring the P. capsici resistance genes from PM217 depends on host pepper genotypes and aggressiveness of the isolates (Bartual et al., 1991). Pochard et al. (1983) declared that PM217 has low level resistance corresponding to inducibility component. PM217 has high level resistance with the inducibility component but low level resistance at receptivity stage in early infection process to Doganlikarahasan isolate. High level susceptibility of Sena variety to the pathogen has decreased the resistance of PM217 progenies despite using complex breeding program for introgression of resistance genes to the progenies. On the other hand, CM334 displayed the highest level of resistance for the four resistance components determining nine additive

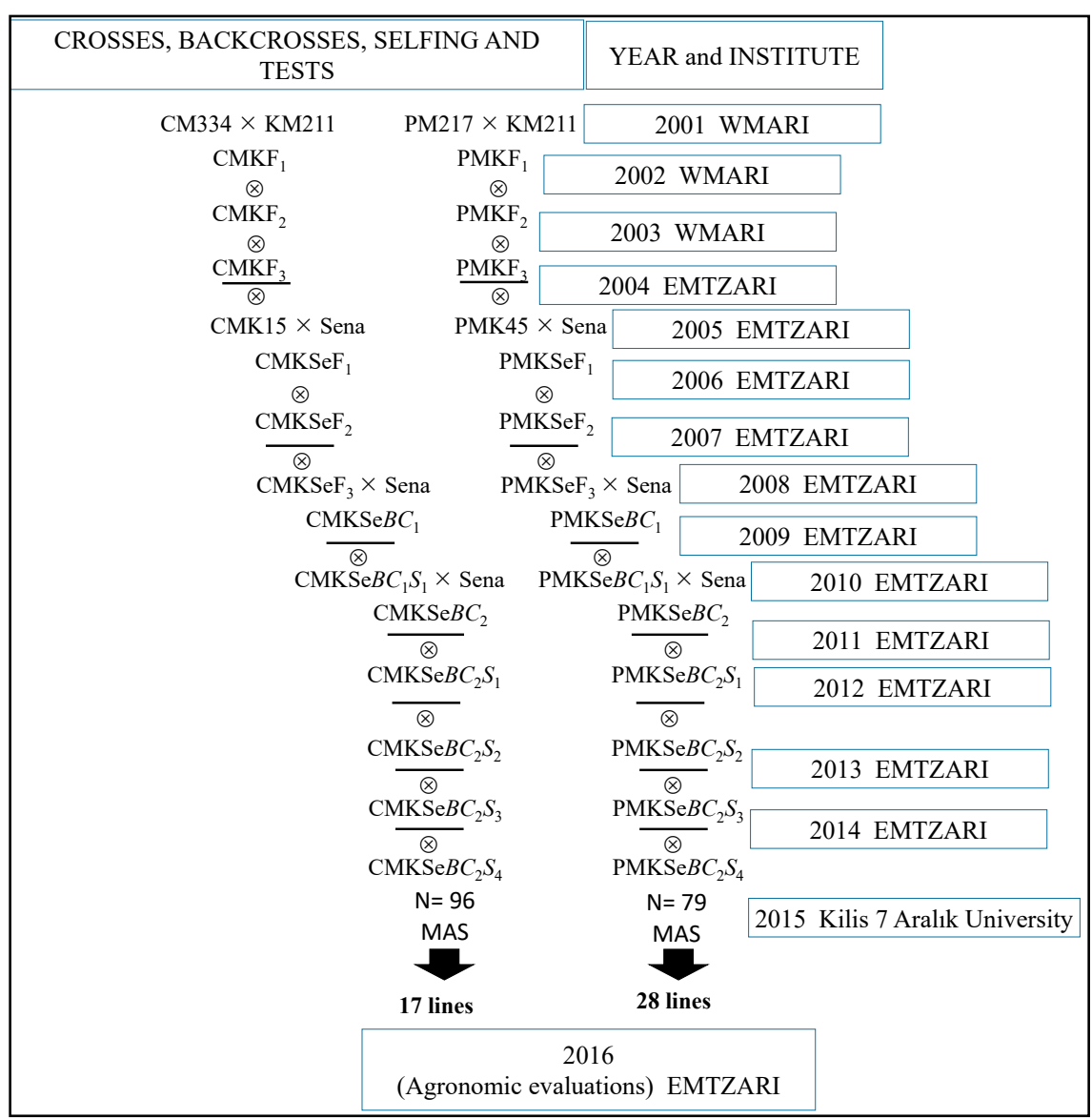

Figure 1. Schematic diagram of improved lines derived from CM334 and PM217; CM334: Criollo de Morelos 334; PM: PM217= PI201234; K: KM211; Se: Sena; $B C$ : Backcross; $S$ : Selfing population X: crossing; (x) : self-pollination - : stem inoculation test N: population size MAS: Marker Assisted Selection. Turkey, Kilis 7 Aralik University, 2013-2016. 
regions and is more effective to improve high level resistant progenies. CM334 has three resistance components in addition to root rot index; bell pepper genotype Vania and pungent Indian genotype Perennial have different level of resistance at receptivity, inducibility and stability stage (Thabuis et al., 2003).

The chromatogram of C-18 and C-29 showed that three regions related to the resistance conferring different levels of inducibility, receptivity and stability could be transferred by the breeding program. Thirteen improved lines produced expected size amplicons

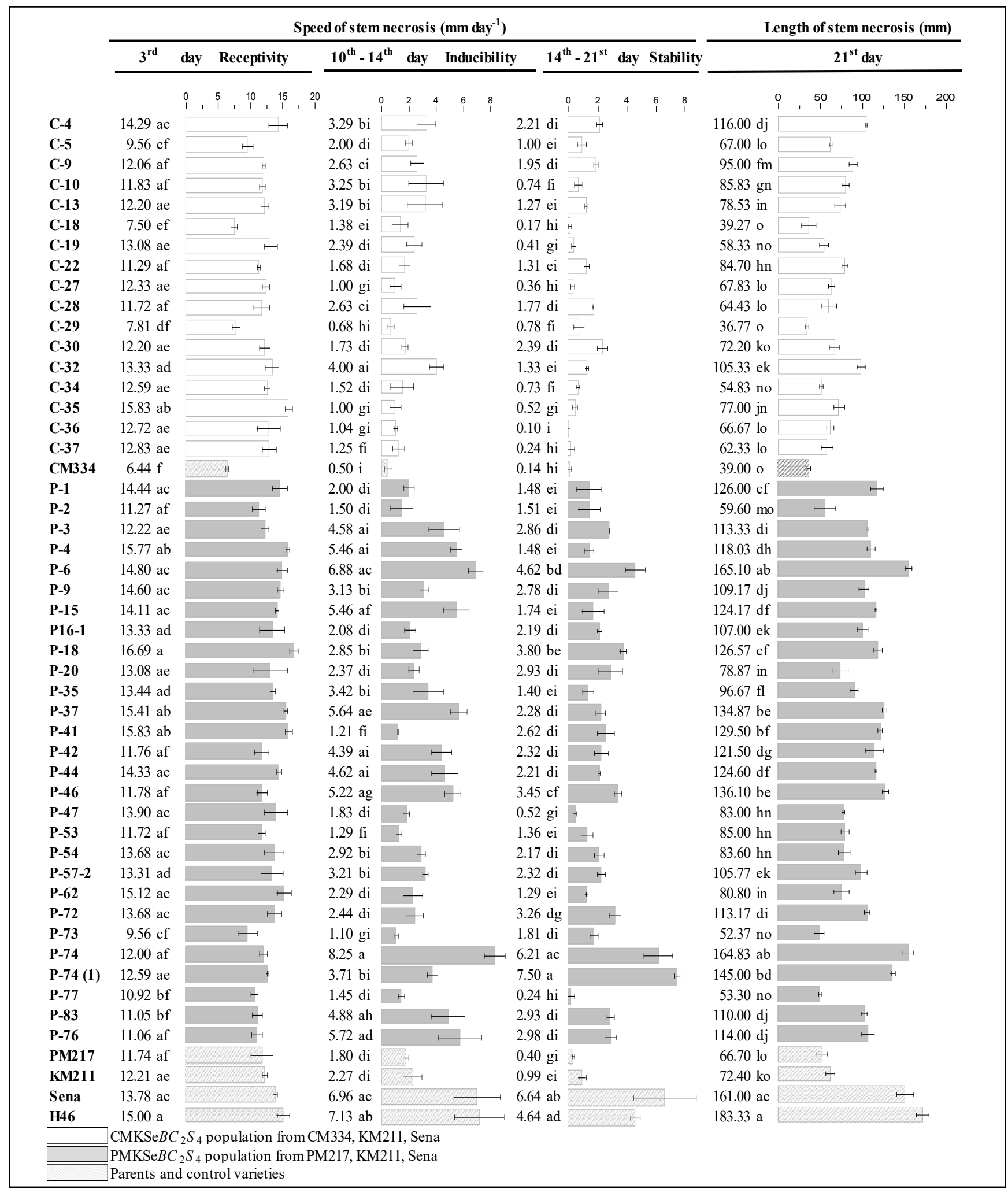

Figure 2. Speed and length of stem necrosis caused by Phytophthora capsici of CMKSe $B C_{2} S_{4}$ and PMKSe $B C_{2} S_{4}$ populations and parents (Capsicum annuum). Turkey, Kilis 7 Aralik University, 2013-2016. 
by all three markers and ten lines were codominant related to ASC031 while only one was corresponding to ASC037 (Figure 3). Fourteen lines improved from different sources possessed one or two resistance components. C-5, P-73 and $\mathrm{P}-77$ were classified as resistant in response to the pathogen at inducibility, receptivity and stability stage. C-27, C-28, C-34, C-37, PM217 and P-2 did not resist to the pathogen at the first three days of the inoculation and they were accepted as moderately resistant with high level resistance corresponding to inducibility and stability components.

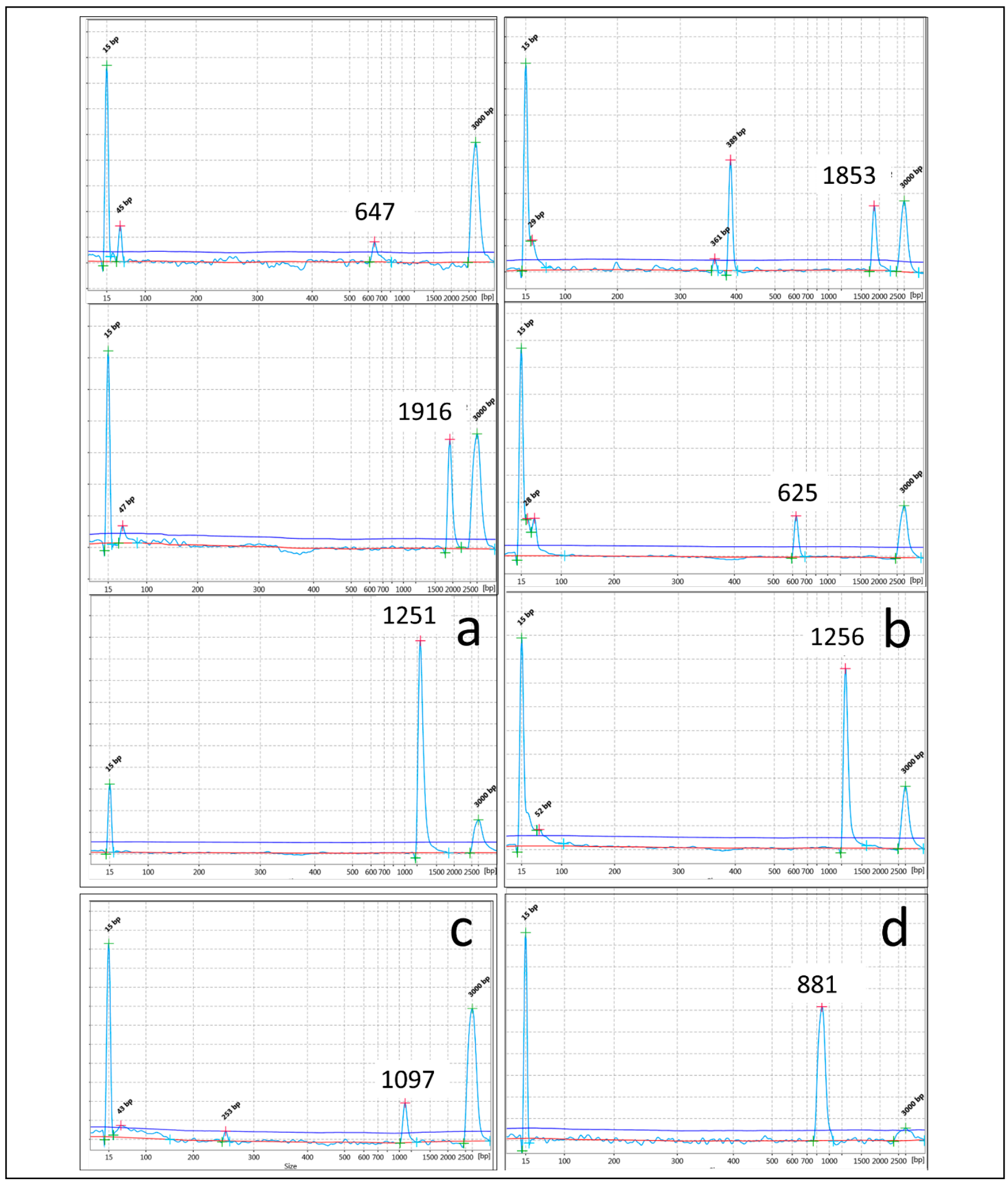

Figure 3. Capillary electrophoresis chromatograms of C-29 (a) and C-18 (b) lines amplified by ASC035 ( $\approx 650$ bp), ASC037 ( $\approx 1900$ bp) and ASC031 ( $\approx 1250$ bp) primers. Codominant response of C-29 line after restricted by HaeIII (c) and P-2 line restricted by EcoRI (d). Turkey, Kilis 7 Aralik University, 2013-2016. 
Other genotypes, except for H46, Sena, P74, P74-1 and P6, straggled between resistant and susceptible genotypes. Control line H46 and variety Sena were quietly separated along with P74, P74-1 and P6 and considered as susceptible genotypes (Figure 4).

After extensive breeding program including crossing, self-pollination and testing process new high-level resistant lines C-29 and C-18 have been improved from CM334 parent as resistant. Also, P-73 and P-77 have been improved from PM217 and KM211 (selected resistant line from local population) as resistant and more yielding lines than Sena commercial chili pepper variety cultivated widespread in the region. Improving resistant lines or varieties to Phytophthora capsici is more complex and requires new approaches such as local inspirations (Oelke et al., 2003). Carvalho et al. (2017) have improved hybrid pepper varieties from CM334 resistant to multiple pathogens including P. capsici. Andrés Ares et al. (2005)

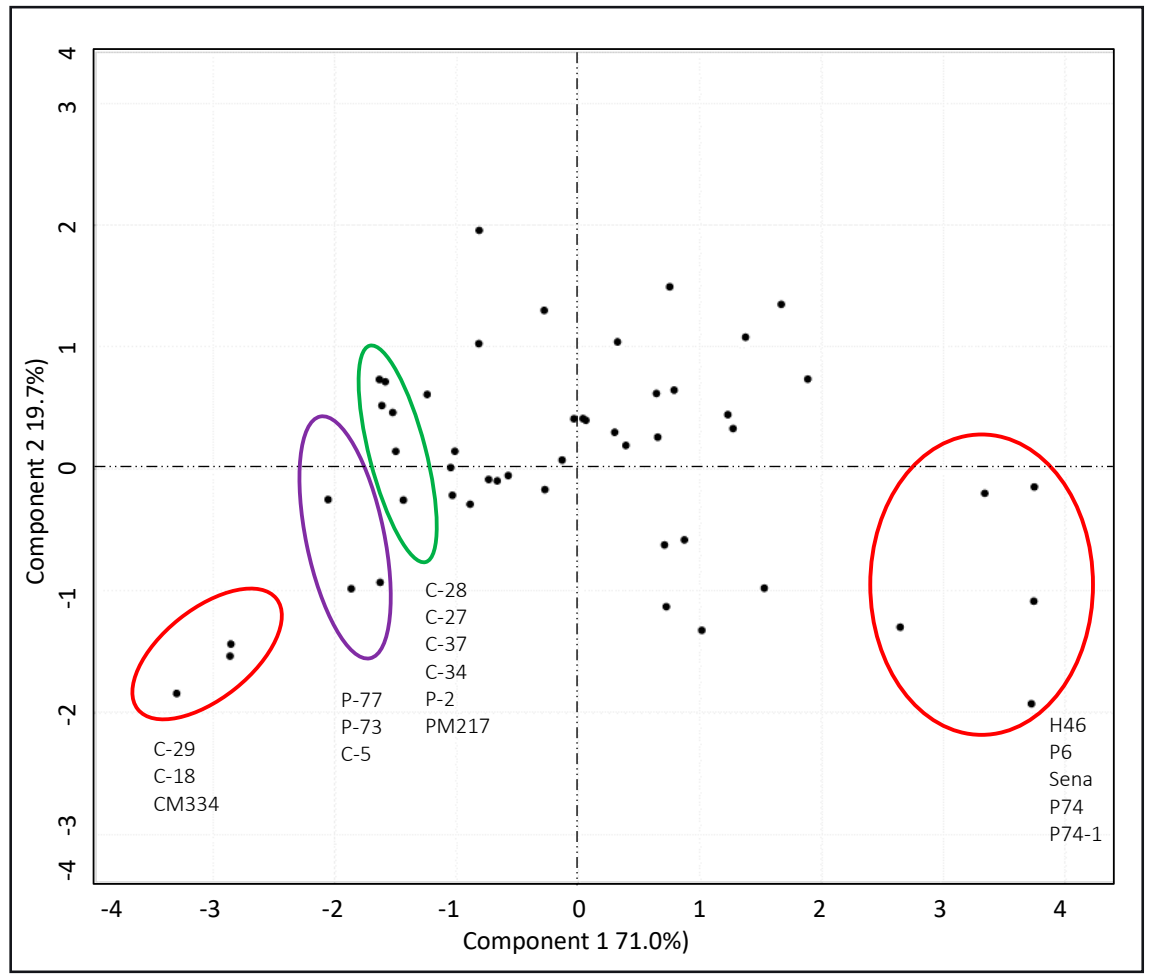

Figure 4. Grouping Capsicum annuum lines by principal component analysis related to speed of stem necrosis [ $3^{\text {rd }}$ day (REC); $10^{\text {th }}-14^{\text {th }}$ day (IND); $14^{\text {th }}-21^{\text {st }}$ day (STA) $]$ and length of stem necrosis values caused by Phytophthora capsici. Turkey, Kilis 7 Aralik University, 2013-2016.

Table 1. Paired t-test correlated responses of CMKSe $B C_{2} S_{4}$ from CM334 and PMKSe $B C_{2} S_{4}$ from PM217 populations related to agronomic traits and resistance components to Phytophthora capsici. Turkey, Kilis 7 Aralik University, 2013-2016.

\begin{tabular}{llccccc}
\hline Variable & Components & CM334 & PM217 & Differences $|\mathbf{x}|$ & Std error & Prob $>|\mathbf{t}|$ \\
\hline \multirow{2}{*}{ Speed of stem necrosis } & $3^{\text {rd }}$ day (REC) & 7.22 & 10.94 & 3.72 & 0.0203 & $<.0001$ \\
(mm/day) & $14^{\text {th }}$ day (IND) & 6.51 & 9.13 & 2.62 & 0.0333 & $<.0001$ \\
& $21^{\text {st }}$ day (STA) & 3.59 & 3.98 & 0.39 & 0.0415 & $<.0001$ \\
\hline Fruit width (mm) & & 61.61 & 64.46 & 2.85 & 2.9176 & 0.3611 \\
Fruit length (mm) & & 18.46 & 17.99 & 0.47 & 0.8098 & 0.2457 \\
Fruit flesh thickness (mm) & 1.36 & 1.44 & 0.08 & 0.0433 & 0.2876 \\
Fruit weight (g) & 6.77 & 7.14 & 0.37 & 0.3983 & 0.4692 \\
Yield (t ha ${ }^{-1}$ ) & & 16.77 & 20.97 & 4.20 & 1.2100 & 0.0078 \\
\hline
\end{tabular}

Box 1. Pairwise correlation between three resistance components $\left[3^{\text {rd }}\right.$ day (REC) $14^{\text {th }}$ day (IND) $21^{\text {st }}$ day (STA) $]$ and length of stem necrosis at $21^{\text {st }}$ day. Turkey, Kilis 7 Aralik University, 2013-2016.

\begin{tabular}{lcccc}
\hline Variable & by variable & correlation & SignifProb & Plot Corr \\
\hline Length of stem necrosis & REC & 0.5917 & 0.0000 & \\
Length of stem necrosis & IND & 0.8365 & 0.0000 & \\
Length of stem necrosis & STA & 0.8071 & 0.0000 & \\
STA & REC & 0.2929 & 0.0390 & \\
STA & IND & 0.7024 & 0.0000 & \\
IND & REC & 0.3370 & 0.0167 & \\
\hline
\end{tabular}


have observed no completely resistant accessions to $P$. capsici blight in Spain but they have indicated that the resistant varieties could be improved by crossing using recurrent selection. New resistant Capsicum sources have been determined useful for improving varieties that could resist to domestic strains of $P$. capsici in Korea (Mo et al., 2014) and Japan (Sugita et al., 2006).

Receptivity, inducibility and stability components significantly and positively correlated with each other and length of stem necrosis at the $21^{\text {st }}$ day post inoculation. Response of the genotypes at the inducibility, deceleration of the necrosis length stage highly correlated with their resistance. Stability component also affected the length of stem necrosis of the improved lines. In consideration of the pairwise correlation of the speed and length of the stem necrosis, resistance of the genotypes at the inducibility and stability components was more effective in resisting to the $P$. capsici (Box 1).

Inducibility and stability components are more effective than receptivity at early infection stage to resist the $P$. capsici. Thabuis et al. (2004a) have indicated that resistance at stability is highly correlated with resistance whereas receptivity is less correlated. Lefebvre \& Palloix (1996) have observed a weak correlation between inducibility and other resistance component. In this study, inducibility has been found highly correlated with stability and length of stem necrosis. Mallard et al. (2013) proposed a new QTL on chromosome 5 related to broad-spectrum resistance in which are significantly interacted to inducibility and stability.

Amplicons of C-18, C-29 and CM334 were close to the expected size with all three markers. Base sizes of C-5, P-73, P-77, C-27, C-28, C-34, C-37, PM217 and P-2 lines were distinct from 11 to 58 base pairs (bp) for ASC 035, 69 to $165 \mathrm{bp}$ for ASC037 and 22 to $72 \mathrm{bp}$ for ASC031. $\mathrm{C} 30$ and $\mathrm{C} 35$ lines were amplified with ASC035 markers on $10^{\text {th }}$ chromosome and ASC037 on $5^{\text {th }}$ chromosome. P1, P6, P18 and P41 lines had only one of the resistance components by matching with ASC031 marker in the $2^{\text {nd }}$ chromosome. The C-32 and C-4 lines
Table 2. Fruit characteristics and yield of control lines, varieties, $\mathrm{CMKSe} B C_{2} S_{4}$ and PMKSe $B C_{2} S_{4}$ populations. Turkey, Kilis 7 Aralik University, 2013-2016.

\begin{tabular}{|c|c|c|c|c|c|}
\hline${ }^{z}$ Genotype & $F L^{x}$ & $\mathbf{F W}^{\mathbf{x}}$ & FFT & $\mathrm{FWe}^{\mathrm{x}}$ & Yield $^{x}$ \\
\hline $\mathrm{P}-1$ & $63.50 \mathrm{ce}$ & 19.7 bj & 1.6 & 7.57 bf & 20.68 al \\
\hline P-2 & 53.60 ef & $16.1 \mathrm{nw}$ & 1.3 & $4.57 \mathrm{fh}$ & $16.84 \mathrm{fn}$ \\
\hline P-3 & $65.90 \mathrm{ce}$ & $16.9 \mathrm{jt}$ & 1.3 & $6.17 \mathrm{bh}$ & 15.65 in \\
\hline P-4 & $80.60 \mathrm{~cd}$ & 17.1 is & 1.4 & $6.27 \mathrm{bh}$ & $17.03 \mathrm{fn}$ \\
\hline P-6 & $67.20 \mathrm{ce}$ & $15.9 \mathrm{pw}$ & 1.3 & 5.92 bh & $25.01 \mathrm{ad}$ \\
\hline P-9 & $66.50 \mathrm{ce}$ & $17.0 \mathrm{jt}$ & 1.4 & $6.87 \mathrm{bg}$ & 22.17 ai \\
\hline P-15 & $69.70 \mathrm{ce}$ & $18.0 \mathrm{er}$ & 1.7 & $8.07 \mathrm{bd}$ & 20.70 al \\
\hline P16-1 & $62.50 \mathrm{cf}$ & $15.7 \mathrm{qw}$ & 1.2 & $5.37 \mathrm{ch}$ & $18.07 \mathrm{dn}$ \\
\hline P-18 & $62.60 \mathrm{cf}$ & $21.0 \mathrm{ad}$ & 1.4 & 6.57 bh & 20.44 al \\
\hline P-20 & $65.20 \mathrm{ce}$ & 20.8 ae & 1.6 & $7.87 \mathrm{bd}$ & $15.98 \mathrm{hn}$ \\
\hline P-35 & $59.80 \mathrm{df}$ & $17.5 \mathrm{gs}$ & 1.5 & $8.27 \mathrm{bd}$ & 19.54 bn \\
\hline P-37 & $64.80 \mathrm{ce}$ & $17.8 \mathrm{fr}$ & 1.4 & $7.47 \mathrm{bf}$ & $25.80 \mathrm{ac}$ \\
\hline P-41 & $69.80 \mathrm{ce}$ & $16.8 \mathrm{ju}$ & 1.5 & $8.77 b$ & 22.59 ai \\
\hline P-42 & $60.20 \mathrm{df}$ & 17.4 hs & 1.4 & 8.24 bd & 22.34 ai \\
\hline P-44 & $70.40 \mathrm{ce}$ & 20.0 bh & 1.4 & 8.27 bd & $23.21 \mathrm{ag}$ \\
\hline P-46 & 70.70 ce & $14.0 \mathrm{ux}$ & 1.3 & 6.27 bh & 21.64 aj \\
\hline P-47 & $40.90 \mathrm{f}$ & $15.6 \mathrm{rw}$ & 1.5 & 7.47 bf & $19.69 \mathrm{bm}$ \\
\hline$P-53$ & $65.70 \mathrm{ce}$ & 20.1 bh & 1.5 & $7.97 \mathrm{bd}$ & $18.16 \mathrm{dn}$ \\
\hline P-54 & $69.80 \mathrm{ce}$ & 20.1 bh & 1.5 & $7.87 \mathrm{bd}$ & 22.33 ai \\
\hline P-57-2 & $64.40 \mathrm{ce}$ & $18.5 \mathrm{cq}$ & 1.4 & $7.07 \mathrm{bg}$ & 17.64 en \\
\hline P-62 & $66.10 \mathrm{ce}$ & $18.4 \mathrm{dr}$ & 1.5 & $7.33 \mathrm{bf}$ & $18.22 \mathrm{dn}$ \\
\hline P-72 & 57.70 ef & 20.1 bh & 1.6 & $6.17 \mathrm{bh}$ & 24.73 ae \\
\hline P-73 & $61.40 \mathrm{cf}$ & $16.3 \mathrm{Iw}$ & 1.4 & $6.27 \mathrm{bh}$ & $20.71 \mathrm{al}$ \\
\hline P-74 & $72.20 \mathrm{ce}$ & 18.9 co & 1.6 & 7.77 be & $26.90 \mathrm{a}$ \\
\hline P-74 (1) & 56.40 ef & 18.9 bn & 1.4 & $6.97 \mathrm{bg}$ & 23.79 af \\
\hline P-77 & $66.50 \mathrm{ce}$ & $19.9 \mathrm{bi}$ & 1.8 & $8.77 b$ & $21.05 \mathrm{ak}$ \\
\hline P-83 & $65.60 \mathrm{ce}$ & $18.7 \mathrm{cp}$ & 1.6 & 7.57 bf & $19.68 \mathrm{bm}$ \\
\hline P-76 & $65.20 \mathrm{ce}$ & $16.7 \mathrm{kv}$ & 1.4 & $6.07 \mathrm{bh}$ & $26.62 a b$ \\
\hline C-4 & $68.34 \mathrm{ce}$ & $20.1 \mathrm{bh}$ & 1.4 & $8.67 b$ & 22.51 ai \\
\hline$C-5$ & $64.86 \mathrm{ce}$ & $18.2 \mathrm{dr}$ & 1.2 & 7.57 bf & $16.05 \mathrm{hn}$ \\
\hline C-9 & 54.65 ef & $18.3 \mathrm{dr}$ & 1.5 & 7.77 be & $17.30 \mathrm{fn}$ \\
\hline C-10 & $60.69 \mathrm{df}$ & $14.8 \mathrm{sw}$ & 1.3 & $5.47 \mathrm{ch}$ & $14.63 \mathrm{jm}$ \\
\hline C-13 & $62.70 \mathrm{cf}$ & $19.1 \mathrm{bm}$ & 1.4 & $6.37 \mathrm{bh}$ & $12.58 \mathrm{mn}$ \\
\hline C-18 & $58.43 \mathrm{df}$ & $16.2 \mathrm{mw}$ & 1.4 & $4.67 \mathrm{eh}$ & 15.81 in \\
\hline C-19 & 57.72 ef & $17.5 \mathrm{gs}$ & 1.3 & $5.17 \mathrm{dh}$ & 17.70 en \\
\hline C-22 & $83.70 \mathrm{bc}$ & $13.8 w x$ & 1.3 & $6.27 \mathrm{bh}$ & 22.99 ah \\
\hline C-27 & $72.33 \mathrm{ce}$ & $16.2 \mathrm{mw}$ & 1.4 & $6.97 \mathrm{bg}$ & $17.23 \mathrm{fn}$ \\
\hline C-28 & 50.98 ef & $19.1 \mathrm{bl}$ & 1.4 & $6.27 \mathrm{bh}$ & $18.01 \mathrm{dn}$ \\
\hline C-29 & 53.96 ef & 21.4 ac & 1.3 & $6.77 \mathrm{bh}$ & 15.78 in \\
\hline C-30 & $58.64 \mathrm{df}$ & $18.2 \mathrm{dr}$ & 1.6 & $6.47 \mathrm{bh}$ & $14.14 \mathrm{kn}$ \\
\hline C-32 & 56.28 ef & $20.4 \mathrm{bg}$ & 1.3 & 7.47 bf & 13.67 In \\
\hline C-34 & $60.62 \mathrm{df}$ & 19.2 bk & 1.3 & $6.97 \mathrm{bg}$ & $17.95 \mathrm{dn}$ \\
\hline C-35 & $60.15 \mathrm{df}$ & $18.1 \mathrm{dr}$ & 1.2 & $6.47 \mathrm{bh}$ & $13.80 \ln$ \\
\hline C-36 & $63.01 \mathrm{cf}$ & $23.7 \mathrm{a}$ & 1.5 & $8.37 \mathrm{bc}$ & $16.11 \mathrm{gn}$ \\
\hline C-37 & $60.23 \mathrm{df}$ & $19.5 \mathrm{bk}$ & 1.5 & 7.27 bf & $18.87 \mathrm{cn}$ \\
\hline
\end{tabular}


Table 2 continuation

\begin{tabular}{lclllll}
\hline yGenotype & FL $^{\mathbf{x}}$ & FW $^{\mathbf{x}}$ & FFT & FWe $^{\mathbf{x}}$ & Yield $^{\mathbf{x}}$ \\
\hline BT-46 & $68.16 \mathrm{ce}$ & $16.4 \mathrm{ou}$ & 1.2 & $5.66 \mathrm{dh}$ & $15.36 \mathrm{~km}$ \\
Maraş 1 & $56.31 \mathrm{ef}$ & $21.4 \mathrm{ab}$ & 1.2 & $7.20 \mathrm{bf}$ & $15.28 \mathrm{kn}$ \\
H46 & $67.10 \mathrm{ce}$ & $14.3 \mathrm{vw}$ & 1.0 & $4.14 \mathrm{~h}$ & $13.81 \mathrm{mn}$ \\
Carliston & $121.50 \mathrm{a}$ & $19.8 \mathrm{bh}$ & 1.9 & $12.73 \mathrm{a}$ & $17.78 \mathrm{fm}$ \\
Sena & $67.37 \mathrm{ce}$ & $20.1 \mathrm{bf}$ & 1.4 & $8.40 \mathrm{~b}$ & $17.65 \mathrm{gn}$ \\
S.Demre & $100.40 \mathrm{~b}$ & $12.2 \mathrm{x}$ & 1.7 & $5.83 \mathrm{ch}$ & $15.49 \mathrm{kn}$ \\
PR-90 & $62.53 \mathrm{de}$ & $14.5 \mathrm{tw}$ & 1.3 & $4.47 \mathrm{gh}$ & $13.60 \mathrm{n}$ \\
\hline
\end{tabular}

'Mean separation within the columns by LS Means Differences Student's t multiple range test at $\mathrm{p} \leq 0.05 .{ }^{\mathrm{y}} \mathrm{CMKSe} B C_{2} S_{4}$ population from CM334, KM211, Sena. ${ }^{\mathrm{z}} \mathrm{PMKSe} B C_{2} S_{4}$ population from PM217, KM211, Sena. "Genotypes were evaluated in augmented design as control lines and varieties. FW: fruit width $(\mathrm{mm}) \mathrm{FL}$ : fruit length $(\mathrm{mm}) \mathrm{FFT}$ : fruit flesh thickness $(\mathrm{mm})$ FWe: fruit weight $(\mathrm{g})$ yield $\left(\mathrm{t} \mathrm{ha}^{-1}\right)$.

were the genotypes that had the only resistance gene indicated by the marking of ASC 037 on the $5^{\text {th }}$ chromosome. C 36 line had the resistance genes on the $2^{\text {nd }}$ and $5^{\text {th }}$ chromosomes coexist. Many lines derived from PM217 had only the resistance gene on the $10^{\text {th }}$ chromosome. Hat46, Sena, P6, P74 and P74-1 lines did not possess any resistance genes related to molecular markers.

Molecular markers and stem inoculation tests have proved that resistance of lines can be different despite the genotypes have same alleles. Seven CM334 and three PM217 originated lines have produced amplicons by using three markers but these lines have placed in three different groups according to principal component analysis related to their speed of stem necrosis (Figure 4). Marker-assisted selection provides many advantages for plant breeding especially determining polygenic characters. It is accepted as a promising tool for breeding quantitative resistance (Thabuis et al., 2004a). However applications of molecular markers in diverse germplasms are generally limited because of phenotype and genotype mismatch (Barchenger et al., 2018). Epistasis and additive effect among resistance genes used in this study and other genes providing resistance may have affected on response of improved lines to pathogen. Lawson et al. (1997) indicated that genetic background can decrease molecular assisted selection (MAS) efficiency and phenotypic reactions arise under different gene effect. However in this study molecular markers have confirmed the resistance of the improved chili pepper lines selected after inoculation tests.

\section{Agronomic traits}

With this breeding program, new resistant chili pepper lines have been improved as resistant as CM334 and suitable for condiment producing. These lines can produce fresh chili pepper presenting almost the yield of Sena variety registered for the purpose of spice pepper production. PM217 has generated more yielding lines but lower resistance level than progenies of CM334. The most yielding line improved from PM217 resistance source was P-74 with $26.90 \mathrm{t} \mathrm{ha}^{-1}$ fresh chili yield while the highest yield $\left(22.99 \mathrm{t} \mathrm{ha}^{-1}\right)$ was harvested from C-22, improved from CM334. The longest fruit (121.49 $\mathrm{mm}$ ) was observed on Carliston variety and the shortest fruits $(40.87 \mathrm{~mm})$ were harvested from line P-47. C-22 line had the longest fruit among the improved lines with $83.70 \mathrm{~mm}$ length. The highest fruit width $(23.66 \mathrm{~mm})$ was observed in C-36. S. Demre, and P-47 genotypes presented the narrowest fruits with $12.17 \mathrm{~mm}$ and $15.63 \mathrm{~mm}$, respectively. Fruit weight varied between $12.73 \mathrm{~g}$ (Carliston) and $4.14 \mathrm{~g}$ (H46).

The highly resistant lines C-18 produced $15.81 \mathrm{t} \mathrm{ha}^{-1}$ and $\mathrm{C}-29$ produced $15.78 \mathrm{t} \mathrm{ha}^{-1}$ fresh chili pepper yields. The fresh chili pepper harvested from resistant lines C-5, P-73 and P-77 yielded $16.05,20.71$ and $21.05 \mathrm{t} \mathrm{ha}^{-1}$ respectively. Moderately resistant lines C-27, C-28, C-34, C-37 and P-2 showed 17.23, 18.01, 17.95, 18.87 and $16.84 \mathrm{t} \mathrm{ha}^{-1}$ fresh chili pepper yields respectively. The lines were significantly different by their fruit weight, fruit length and fruit width values individually (Table 2).

The two breeding populations for agronomic components showed that there were no differences between $\mathrm{BC}_{2} \mathrm{~S}_{4}$ populations of CM334 and PM217 except for yield values. Mean differences related to yield between two improved populations originated from CM334 and PM217 was $4.20 \mathrm{t}$ $\mathrm{ha}^{-1}$. PM217 was found as more suitable resistance source to improve $P$. capsici resistant chili pepper lines than CM334 for transferring yield component traits. Fruit width, fruit length, fruit flesh thickness and fruit weight were not affected from resistance source (Table $1)$.

Local genotype KM211 having resistance to the pathogen featured in breeding program has enabled to improve lines as resistant as CM334 and satisfying resistant lines from PM217. More yielding than registered varieties and satisfying resistant lines could be improved using PM217. Resistant alleles have been originated more frequently from the resistant parent, but they occasionally have been originated from the susceptible parent. Susceptible parents can carry resistance gene and resistance can be transferred from $3^{\text {rd }}$, $5^{\text {th }}$ and $11^{\text {th }}$ chromosomes (Thabuis et al., 2003).

Turkey is one of the countries having most aggressive $P$. capsici isolates in the World (Oelke et al., 2003). Two breeding populations, including local resistance source KM211 to Phytophthora blight from CM334 and PM217, have been compared by three resistance components (receptivity, inducibility, stability) and fruit and yield characteristics. CM334 was a more effective genotype to transfer all three component of $P$. capsici resistance to its generations. PM217 could be useful for improving high yielding, suitable for spice processing and satisfactorily resistant chili lines to the pathogen. Improving new varieties to Phytophthora capsici not only requires local resistant genotypes but also complex breeding strategies 
including self-pollination, backcrossing and combination of different resistance sources.

\section{ACKNOWLEDGEMENTS}

This study was partly supported by General Directorate of Agricultural Research and Policies with TAGEM/ $\mathrm{BBAD} / 12 / \mathrm{A} 09 / \mathrm{PO} 2 / 01$ project number. We thank Dr. Münevver GÖÇMEN for supplying seeds at $\mathrm{F}_{2}$ generation. Thanks to seven anonymous reviewers for their constructive comments.

\section{REFERENCES}

ALCANTARA, P; BOSLAND, PW. 1993. A seedling screening technique for foliar blight (Phytophthora capsici) of Capsicum. Capsicum and Eggplant Newsletter 12: 83-84.

ANDRÉS ARES, JL; RIVERA MARTÍNEZ, A; FERNÁNDEZ PAZ, J. 2005. Resistance of pepper germplasm to Phytophthora capsici isolates collected in northwest Spain. Spanish Journal of Agricultural Research 3: 429-436.

BARCHENGER, DW; LAMOUR, KH; BOSLAND, PW. 2018. Challenges and strategies for breeding resistance in Capsicum annuum to the multifarious pathogen, Phytophthora capsici. Frontiers in Plant Science 9: 628.

BARKSDALE, TH; PAPAVIZAS, GC; JOHNSTON, SA. 1984. Resistance to foliar blight and crown rot of pepper caused by $P$. capsici. Plant Disease 68: 506-509.

BARTUAL, R; CARBONELL, EA; MARSAL, JI; TELLO, JC; CAMPOS, T. 1991. Gene action in the resistance of peppers (Capsicum annuиm) to Phytophthora stem blight (Phytophthora capsici L.). Euphytica 54: 195-200.

BONNET, J; DANAN, S; BOUDET, C; BARCHI, L; SAGE-PALLOIX, AM; CAROMEL, B; PALLOIX, A; LEFEBVRE, V. 2007. Are the polygenic architectures of resistance to Phytophthora capsici and P. parasitica independent in pepper? Theoretical and Applied Genetics 115: 253-264.

CARVALHO, RC; NOGUEIRA, DW; TICONABENAVENTE, CA; NOGUEIRA, DG; MALUF, WR; GONÇALVES, RJ; SILVA, LF. 2017. Assessment of resistances to multiple pathogens in experimental sweet pepper hybrids. Horticultura Brasileira 35: 48-56.
HAUSBECK, MK; LAMOUR, KH. 2004. Phytophthora capsici on vegetable crops: Research progress and management challenges. Plant Disease 88: 1292-1303.

IRIBARREN, MJ; STECIOW, M; GONZÁLEZ, B; NARDELLI, M. 2019. Prevalence and aetiology of Phytophthora fruit and stem rot of solanaceous and cucurbitaceous crops in the Pampas region of Argentina. Journal of Plant Pathology 1-9.

LAWSON, DM; LUNDE, CF; MUTSCHLER, MA. 1997. Marker-assisted transfer of acylsugar-mediated pest resistance from the wild tomato, Lycopersicon pennellii, to the cultivated tomato, Lycopersicon esculentum. Molecular Breeding 3: 307-317.

LEFEBVRE, V; PALLOIX, A. 1996. Both additive and epistatic effects of QTLs are involved in polygenic induced resistance to diseases: A case study, the interaction pepperPhytophthora capsici Leon. Theoretical and Applied Genetics 93: 503-511.

LEFEBVRE, V; PALLOIX, A; CARANTA, C; POCHARD, E. 1995. Construction of an intraspecific integrated linkage map of pepper using molecular markers and doubled-haploid progenies. Genome 38: 112-121.

MALLARD, S; CANTET, M; MASSIRE, A; BACHELLEZ, A; EWERT, S; LEFEBVRE, V. 2013. A key QTL cluster is conserved among accessions and exhibits broad-spectrum resistance to Phytophthora capsici: a valuable locus for pepper breeding. Molecular Breeding 32: 349-364.

MO, H; KIM, S; WAI, KPP; SIDDIQUE, MI; YOO, H; KIM, BS. 2014. New sources of resistance to Phytophthora capsici in Capsicum spp. Horticulture, Environment, and Biotechnology 55: 50-55.

MONROY-BARBOSA, A; BOSLAND, PW. 2011. Identification of novel physiological races of Phytophthora capsici causing foliar blight using the New Mexico recombinant inbred pepper lines set as a host differential. Journal of the American Society for Horticultural Science 136: 205-210.

OELKE, LM; BOSLAND, PW; STEINER, R. 2003. Differentiation of race specific resistance to Phytophthora root rot and foliar blight in Capsicum annuum. Journal of the American Society for Horticultural Science 128: $213-218$

PALLOIX, A; DAUBÈZE, AM; PHALY, T; POCHARD, E. 1990. Breeding transgressive lines of pepper for resistance to Phytophthora capsici in a recurrent selection system. Euphytica 51: 141-150.

PILET-NAYEL, ML; MOURY, B; CAFFIER, V; MONTARRY, J; KERLAN, MC; FOURNET, S; DUREL, CE; DELOURME, R. 2017. Quantitative resistance to plant pathogens in pyramiding strategies for durable crop protection. Frontiers in Plant Science 8: 1838.

POCHARD, E; DAUBÈZE, AM. 1980. Recherche et valuation des composantes d'une resistance polygenique: la resistance du piment Phytophthora capsici. Annales de L'amélioration des Plantes 26:377-398.

POCHARD, E; MOLOT, PM; DOMINGUEZ, G. 1983. Etude de deux nouvelles sources de résistance à Phytophthora capsici Leon. chez le piment: confirmation de l'existence de trois composantes distinctes dans la résistance. Agronomie 3: 333-342.

QUIRIN, EA; OGUNDIWIN, EA; PRINCE, JP; MAZOUREK, M; BRIGGS, MO; CHLANDA, TS; KIM, KT; FALISE, M; KANG, BC; JAHN, MM. 2005. Development of sequence characterized amplified region (SCAR) primers for the detection of Phyto. 5.2, a major QTL for resistance to Phytophthora capsici Leon. in pepper. Theoretical and Applied Genetics 110: 605-612.

SUGITA, T; YAMAGUCHI, K; KINOSHITA, T; YUJI, K; SUGIMURA, Y; NAGATA, R; TODOROKI, A. 2006. QTL analysis for resistance to Phytophthora blight (Phytophthora capsici Leon.) using an intraspecific doubled-haploid population of Capsicum annuum. Breeding Science 56: 137-145.

SY, O; BOSLAND, PW; STEINER, R. 2005. Inheritance of phytophthora stem blight resistance as compared to phytophthora root rot and phytophthora foliar blight resistance in Capsicum annuum L. Journal of the American Society for Horticultural Science 130: 75-78.

THABUIS, A; LEFEBVRE, V; BERNARD, G; DAUBĖZE, AM; PHALY, T; POCHARD, E; PALlOIX, A. 2004a. Phenotypic and molecular evaluation of a recurrent selection program for a polygenic resistance to Phytophthora capsici in pepper. Theoretical and Applied Genetics 109: 342-351.

THABUIS, A; PALLOIX, A; SERVIN, B; DAUBEZE, AM; SIGNORET, P; LEFEBVRE, V. 2004b. Marker-assisted introgression of 4 Phytophthora capsici resistance QTL alleles into a bell pepper line: validation of additive and epistatic effects. Molecular Breeding 14: 9-20.

THABUIS, A; PALLOIX, A; PFLIEGER, S; DAUBÈZE, AM; CARANTA, C; LEFEBVRE, V. 2003. Comparative mapping of Phytophthora resistance loci in pepper germplasm: evidence for conserved resistance loci across Solanaceae and for a large genetic diversity. Theoretical and Applied Genetics 106: 1473-1485. 